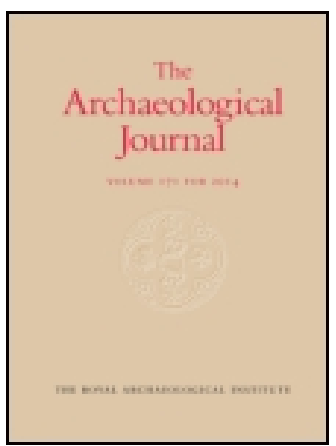

Archaeological Journal

\title{
A Roman Charm from Cirencester
}

\section{F. Haverfield M.A., F.S.A.}

To cite this article: F. Haverfield M.A., F.S.A. (1899) A Roman Charm from Cirencester, Archaeological Journal, 56:1, 319-323, DOI: 10.1080/00665983.1899.10852827

To link to this article: http://dx.doi.org/10.1080/00665983.1899.10852827

曲冓 Published online: 16 Jul 2014.

Submit your article to this journal $\pi$

III Article views: 2

Q View related articles $₫$ 


\section{A ROMAN CHARM FROM CIRENCESTER.}

By F. HAVERFIELD, M.A., F.S.A.

In some excavations near the Victoria Road at Cirencester there was found in 1868 a fragment of painted wall plaster, with the following letters scratched upon it through the surface colouring. In order to ensure that his letters should be even, the inscriber has drawn a guiding line along the bottom of Rotas:

$\mathrm{R} O \mathrm{TAS}$

O P E R A

$\mathrm{T}$ E N E T

A R E P O

$\mathrm{S}$ A T O R

It is now in the Cirencester Museum, where I have been able to examine it. The plaster on which the letters are scratched seems certainly to be Roman, and I am assured by Prof. A. H. Church that the circumstances under which the object was found preclude all suspicion of forgery, as it was taken out of the ground under the eyes of Captain Abbott, then curator of the Museum, and no one benefited pecuniarily by the finding. The letters, too, are such as would naturally be taken to be Roman, notably, the letter A in four out of the five lines. The accompanying plate shows it full size.

The combination of letters used for the inscription was employed as a charm extremely often in the middle ages, and is not uncommonly met with in modern times, but in no instance does it seem to be earlier than the eighth or ninth century. Mr. Heim, in the course of an exhaustive article on Greek and Latin charms, quotes many parallels, and assigns the inscription to some monkish rule. It is, he says, SAT ORARE POTENter ET OPERAre RatiO TuA Sit. This explanation is too subtle and far-fetched, and it conflicts with the Roman origin which it seems natural to assign to the Cirencester specimen. More probably the charm was invented during, and perhaps in the last days 
of, the Roman empire, and was then used to ward off misfortune just as, in the last century at any rate, it was used in Abyssinia and in Brazil against toothache or the bite of a mad dog. At the same time it must be recollected that this Cirencester fragment is the only known instance in which this widespread charm can be attributed to a Roman date. The only other instance which has been suggested to be Roman, is one found at Rochemaure in the Rhone valley near Montelimar, in the south of France. This, however, though ascribed by French writers to a Roman origin and by Hirschfeld to possibly the seventh century, seems really to be mediæval. According to a copy of it made by the Rev. T. V. Bayne, Keeper of the Archives in the University of Oxford, and Student of Christ Church, it is in full as follows :-

\begin{tabular}{|c|c|c|c|c|c|}
\hline $\mathrm{S}$ & $\mathrm{A}$ & $\mathrm{T}$ & $\mathrm{O}$ & $\mathrm{R}$ & GIROV \\
\hline $\mathrm{A}$ & $\mathrm{R}$ & $\mathrm{E}$ & $\mathrm{P}$ & $\mathrm{O}$ & \\
\hline $\mathrm{T}$ & $\mathrm{E}$ & $\mathrm{N}$ & $\mathrm{E}$ & $\mathrm{T}$ & VM \\
\hline $\mathrm{O}$ & $\mathrm{P}$ & $\mathrm{E}$ & $\mathrm{R}$ & $\mathrm{A}$ & \\
\hline $\mathrm{R}$ & $\mathrm{O}$ & $\mathrm{T}$ & $\mathrm{A}$ & $\mathrm{S}$ & MERT FECIT \\
\hline
\end{tabular}

It is, Mr. Bayne tells me, on a slab of terracotta over the door of the choir in the chapel of St. Laurent, about two kilometers west of Rochemaure. The letters given in Mr. Bayne's copy on the right hand side, which were unrecorded by previous explorers, seem to prove that this is one of the many mediæval instances of the puzzle.

Nor can I find any exact parallel to this puzzle among objects of definitely Roman date. The parallels sometimes quoted, such as,

G $\mathrm{R}$ A S

$\mathrm{R} O \mathrm{M} \mathrm{A}$

A $\mathrm{MO} \mathrm{R}$

S A R G 
are, I believe, all certainly mediæval, and the anagrams and "recurring" verses and the like, which were very common in the later empire, are not precise parallels. Such is, for instance, the pentameter,

\section{Roma tibi subito motibus ibit amor,}

which reads the same way backwards and forwards. Such again is the elegiac couplet quoted by Apollinaris Sidonius, IX, 14, 4 :-

Præcipiti modo quod decurrit tramite flumen,

Tempore consumptum jam cito deficiet.

which if read backwards becomes:-

Deficiet cito jam consumptum tempore flumen,

Tramite decurrit quod modo præcipiti.

These have been quoted as parallels, but they are hardly close enough to throw any real light on the matter. More like are some of the "Palindromes" which occur on late pavements and in late poems. As, for instance, on two pavements at Orleansville in Algeria, on one of which is an inscription of which each outer side is AISELCECLESIA while the other has a similar square formed on its four outsides by the letters SODRECASA CERDOS. The former contains on its outside the word Ecclesia, and its inside (it is in all 169 letters) is constructed out of variations on "Sancta Ecclesia," with the curious provision that while Ecclesia appears in full, Sancta always wants its S. Similarly with the other; on the outside Sacerdos is given in full, in the inside Marinus Sacerdos, but here again the first letter of Marinus is carefully omitted. The idea in each case, I suppose, must be in some way to make the thing more of a cryptogram. These seem to presuppose the existence of such shorter devices as that which we have been considering.

[The following references may be added:-R. Heim Incantamenta magica graca et latina in Fleckeisen's Jahrbücher, XIX Supplement, pp. 463-576; Schwartz, Indogermanische Volksglaube, p. 257; Kopp, Beiträge zur grierhischen Excerptenlitteratur, p. 6ذ; Zeitschrift fur Ethnologie, XIX (1887), p. 72 ; Verhandlungen der Berliner Gesellschaft für Anthropologie in the just-mentioned Zeitschrift, 1880-4; Corpus Inscr. Lat., VIII, 9710, 9711. MIr. James Hilton, F.S.A., has very kindly supplied me with a reference to the "Metametrica", of Jean de Lobkuwitz Caramuel, Bishop of Vigevano, Section ccexiv, 
where a seal is mentioned, inscribed with this charm. The "Metametrica," published at Rome in 1663, is a rare book, which appears to be neither in the British Museum nor in the Bodleian Library.

It will be noticed that I have said nothing above about the derivation of "Arepo." This is because I do not see that there is anything definite that can be said. The word has often been connected with the Gaulish arepennis, a measure of ground, a word itself connerted with arare, to plough. If this he so arepo may mean the ploughman or the plough, and the charm may be of Celtic, that is, Gaulish or British, origin. The French scholar, Ernault, translates "the laborer, Arepo, holds the wheels with care," and if we substitute plough or ploughman for Arepo, we get a certain sense. But in devices of this sort, it is not in the least necessary that all the words should have sense. The fundamental idea in them is to arrange letters in such a way that certain combinations recur and recur, and it is not imperative that every recurrence should be intelligible.]

\section{Note By the Editor.}

I have a record of the charm with the variation of TERET for TENET, but it is fifty years ago, and I have unfortunately not preserved the reference. About that time there were many similar things in Notes and Queries and in Willis's Price Current. This form would be fatal to Mr. Hein's interpretation. The recurring verse Mr. Haverfield quotes was given in Willis's Price Current of March, 1852, as the second of an elegiac,

"Signa te, signa, temere me tangis et angis.

Roma tibi subito motibus ibit amor."

Both read the same backwards and forwards. Again,

"Sacrum pingue dabo, non macrum sacrificabo,"

is a hexmeter and refers to Abel's sacrifice. Reversed, it is a pentameter and refers to Cain's.

"Sacrificabo macrum, non dabo pingue sacrum."

This was in Notes and Queries, xxxvi, p. 141.

Of palindromes, in the church of St. Salvador, Oviedo, on the tomb of one Silo, is a square inscription, where, beginning with the centre letter and working to any corner, vou can read (it is said) 270 ways the legend: SILO PRINCEPS FECIT.

I suppose the first one Mrr. Haverfield quotes was as 
A ROMAN CHARM FROM CIRENCESTER.

follows. If the centre letter was omitted, it is easily supplied.

\begin{tabular}{|c|c|c|c|c|c|c|c|c|c|c|c|c|}
\hline A & I & S & E & L & C & E & C & L & E & S & I & A \\
\hline I & S & E & L & C & E & A & E & C & L & E & S & I \\
\hline S & E & L & C & E & A & T & A & E & C & L & E & S \\
\hline E & L & C & E & A & T & C & T & A & E & C & L & E \\
\hline L & C & E & A & T & C & N & C & T & A & E & C & L \\
\hline C & E & A & T & C & N & A & N & C & T & A & E & C \\
\hline E & A & T & C & N & A & S & A & N & C & T & A & E \\
\hline C & E & A & T & C & N & A & N & C & T & A & E & C \\
\hline L & C & E & A & T & C & N & C & T & A & E & C & L \\
\hline E & L & C & E & A & T & C & T & A & E & C & L & E \\
\hline S & E & L & C & E & A & T & A & E & C & L & E & S \\
\hline I & S & E & L & C & E & A & E & C & L & E & S & I \\
\hline A & I & S & E & L & C & E & C & L & E & S & I & A \\
\hline
\end{tabular}

Begin with the large $\mathrm{S}$ in the middle and go up or down, right or left, turning off at a right angle at any letter till you come to a corner A, it always reads SANCTA ECLESIA. It is very difficult to count the number of different ways, but they must be many more than 270 . 